\title{
PREFERRED LEARNING STYLES OF STUDENTS MAJORING IN CHEMISTRY, PHARMACY, TECHNOLOGY AND DESIGN
}

\author{
Tetiana Derkach \\ Kyiv National University of Technologies and Design, Kyiv, Ukraine \\ derkach.tm@knutd.edu.ua
}

\begin{abstract}
Research on students' preferences in learning styles is a topical issue of modern education because understanding the learning styles promotes individualisation of the teaching process. The existing preferences in learning styles of students of four areas of training have been studied by the Felder-Soloman Index of Learning Styles. Technology students have the most balanced learning profile: the preference of any style in all dimensions does not exceed $70 \%$. Future chemists and pharmacists are characterised by the apparent preferences of visual, sensitive and active styles (at the level of $80 \%$ ), as well as a moderate preference of sequential style ( $70 \%$ ). Design students exhibit distinct domination of visual style $(>95 \%)$ over verbal one $(<5 \%)$. In three other dimensions, a moderate preference $(60-70 \%)$ of active, sensitive and sequential styles over reflective, intuitive and global styles is observed. Relative invariance of learning styles has been proved by the results of the survey for pharmacy students: the dominant styles are poorly changed during four years of undergraduate study. Increasing reflectivity, intuitiveness and verbality becomes significant for the fifth year of study. However, such changes may be related not so much to the transformation of personality characteristics, but are caused by the additional selection of students when they join their graduate school. The problem of optimal choice of electronic resources for teaching chemistry was illustrated for future chemists and pharmacists with different preferences in a sensitive-intuitive dimension. One preferred learning style (more than $90 \%$ of students are sensitive) dominates among pharmacy students, while up to $20 \%$ of chemists have a pronounced intuitive type of learning. The pedagogical approaches, methods and electronic resources for teaching chemistry, are discussed for students of both specialities.
\end{abstract}

Keywords: learning style; chemistry; pharmacy; design and technology education; Felder-Soloman Index of Learning Styles.

\section{Introduction}

The creation of conditions that help to master the knowledge of various subject fields effectively is an urgent problem of modern education. The development of adaptive learning strategies that take into account both psycho-physiological characteristics of students and changes taking place in their intellectual development is considered as one of the ways that facilitate individualisation of professional training of future specialists and increases the efficiency of the educational process.

The actual problem is the identification of predominant styles of learning, as well as the provision of consistency between the styles of learning and the styles of teaching material. A learning style can be defined as a typical cognitive, emotional and psychological behaviour, serving as a relatively stable indicator of how students feel and interact with the learning environment. This definition accounts for the fact that learning styles are an adaptive strategic response to a situation and depend on different factors (for example, level of interest), and also show themselves as more stable types associated with personal characteristics. A variety of approaches are used to characterise the learning styles of people (Coffield, Moseley, Hall, Ecclestone, 2004; Velusamy, Anouncia, 2013).

There is a lot of evidence that students from different fields of study often demonstrate different preferences in their learning styles (Yaroshenko, Derkach, 2012; Derkach, Starova, 2017). The nature of the emergence of different learning styles in different environments is not finally evident yet. One may suppose that learning styles are, rather, educational strategies that characterise the individual's actions in response to the requirements of a particular learning situation. Thus, the learning styles or individuallyunique ways of educational activity by their very nature may depend directly on the educational technology used, including the teaching methods, types of educational resources, teacher position, status educational institution, etc. (Velusamy, Anouncia, 2013). In turn, individual ways of scholarly activity are formed under the influence of cognitive styles typical of a person (coding and processing styles, staging and solving problems, cognitive attitudes to the world, etc.).

There are rather complex connections between the learning styles and the academic performance of students in various areas of training (Chun Lok, Kuan, 2016; Cetin, 2015; Russo, Mertins, Ray, 2013; Surjono, 2015; Wilson, Narayan, 2014; Ishak, Awang, 2017). Also, the existence of a correlation between the students' success in the study of chemistry and their preferred learning styles, as well as the cognitive load that students experience when working with electronic learning resources, has been established (Derkach, 2011). Understanding the type of preferred learning styles enables teachers of different specialities to design course materials so that they can be equally well-learned by all students. Recognising their own methods of study helps students to master the disciplines by developing a strategy of activity in accordance with their preferences, providing a basis for mastering new patterns of behaviour. Research in 
this area is vital for determining the conditions for the effective training of students through the use of modern information and communication technologies (ICTs), since understanding students' learning styles allows one to optimise a set of electronic learning resources (e-resources) (Derkach, 2013; 2016).

The purpose of this work is an experimental determination and a comparative analysis of the learning preferences inherent in students of different fields of study.

\section{Methods}

Students of two faculties of the Kyiv National University of Technologies and Design (KNUTD), which get trained in four different areas, took part in the survey during 2017-2018 (Table 1).

Students of KNUTD which took part in the survey

Table 1

\begin{tabular}{|l|l|l|l|}
\hline Faculty & Field of study & Year of study & Number of respondents \\
\hline Chemical and Biopharmaceutical Technologies & Pharmacy & $1-5$ & 174 \\
\hline Chemical and Biopharmaceutical Technologies & Chemistry & 3 & 48 \\
\hline Fashion Industry & Design & 4 & 9 \\
\hline Fashion Industry & Technology & 4 & 11 \\
\hline
\end{tabular}

The research was based on the model of learning styles of R. Felder and B. Soloman (thereinafter Felder-Soloman's model). This model, also known as the Felder-Soloman Index of Learning Styles, was initially designed to determine the learning styles of engineering students, but later became a favourite questionnaire tool in other areas of education. Its reliability and validity were repeatedly discussed and validated (Felder, Spurlin, 2005). The model is available for free use since the late nineties (Felder, Soloman, 1997) and involves interviewing respondents and analysing their answers to 44 questions. The results obtained by the survey allow one to evaluate the available preferences in four dimensions. Each dimension consists of two opposite styles or a pair of a style and anti-style and is scored by an 11-point scale. The advantage of one of two opposite styles is estimated on the base of distribution of 11 points between them.

The dimensions of Felder-Soloman's model and a list of the available styles with their brief description are shown in Table 2.

Table 2

Learning styles and dimensions of Felder-Soloman's model

\begin{tabular}{|l|l|l|}
\hline Dimension & Style name (in short) & Description \\
\hline \multirow{2}{*}{$\begin{array}{l}\text { Perception of } \\
\text { information }\end{array}$} & Sensitive (sen) & Awareness of information, facts \\
\cline { 2 - 3 } & Intuitive (int) & Intuition, forming an abstract concept \\
\hline $\begin{array}{l}\text { Sensors for } \\
\text { perception }\end{array}$ & Visual (vis) & Preference to drawings and diagrams \\
\cline { 2 - 3 } $\begin{array}{l}\text { Understanding } \\
\text { information }\end{array}$ & Verbal (vrb) & Preference to the written or oral explanation \\
\cline { 2 - 3 } $\begin{array}{l}\text { Learning } \\
\text { patterns }\end{array}$ & Reflective (ref) & Activity, experimentation \\
\cline { 2 - 3 } & Sequential (seq) & Reflections, observations \\
\cline { 2 - 3 } & Global (glo) & Understanding by jumps, system thinking and synthesis \\
\hline
\end{tabular}

For each respondent, style preferences in all four dimensions were determined on the base of the survey results. The total and relative numbers of respondents of a particular preferred style were calculated. The relative numbers in percentage were used to describe preferred learning styles in different groups of students.

\section{Results}

The results of the study of preferred learning styles among the students of KNUTD major in different fields of training are shown as solid lines on charts in Fig. 1.

The preferred learning styles of students of some world universities obtained from the literature are marked with dashed lines in Fig. 1. A comparison of the experimental results with literature data will be carried out in the next section of the work.

As is seen from Fig. 1, the preferences of future chemists and pharmacists of the KNUTD look similar, they both are characterised by a substantial (more than $80 \%$ of respondents) advantage of styles sen and vis and similar in intensity ( $80 \%)$ advantage of style act. At the same time, in a seq-glo dimension, they demonstrate a more moderate preference to style seq which is at the level of $70 \%$.

Profiles of technology students look a bit more balanced. For any dimension, the dominant style does not exceed $70 \%$. Thus, the prevalence of styles vis and seq is at the level of $70 \%$ of respondents, the advantages of styles act over ref and sen over int are about $60 \%$ and $55 \%$ respectively. 
Despite the extraneous dissimilarity of the profiles of technologists and designers, their teaching profiles are mostly similar in three dimensions, namely, sen-int, act-ref and seq-glo. An essential difference is observed only for a vis-vrb aspect: Designers almost wholly prefer the visual learning style, while about a third of future technologists demonstrate a predominant verbal style.
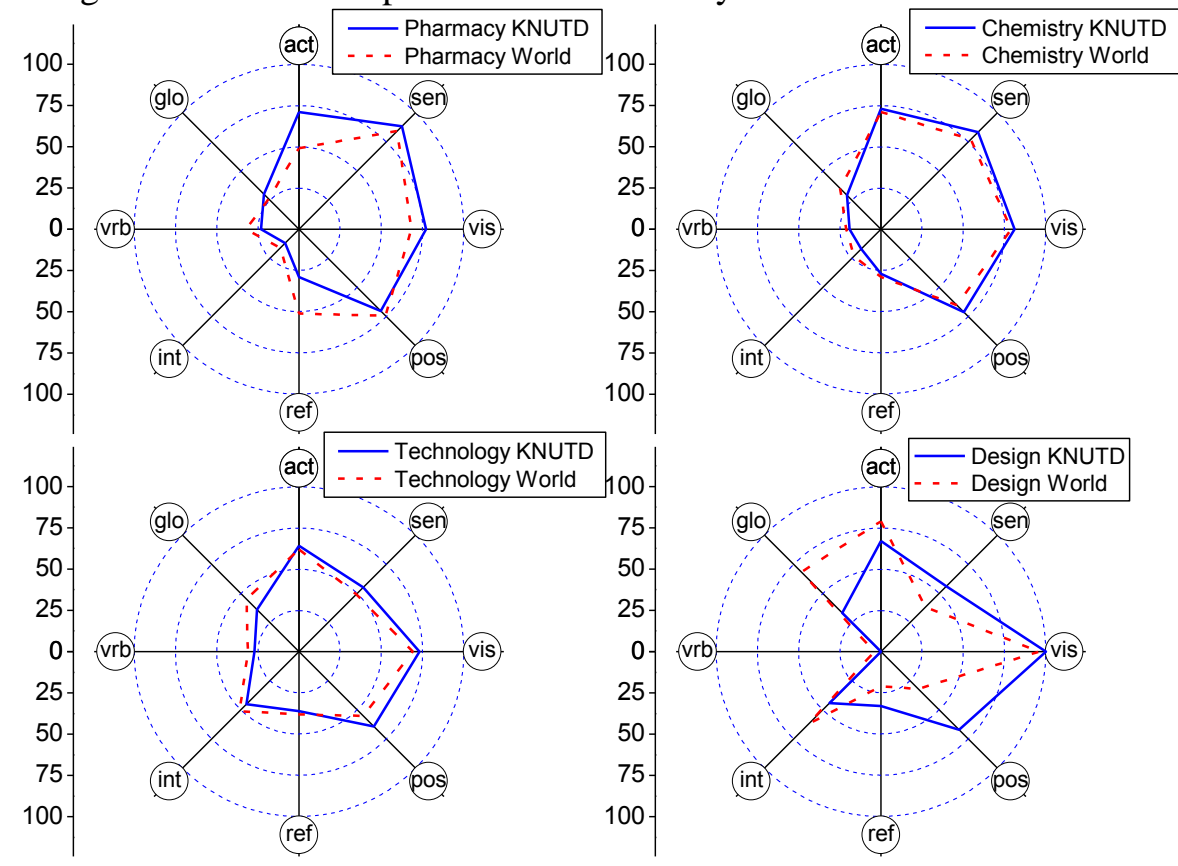

Fig. 1 Preferred learning styles of students of four different fields of study at KNUTD and some world universities

\section{Discussion}

The question arises as to whether the invented behaviour patterns are of a universal nature or they are inherent only to students of a particular year of study in a specific university. Information about the preferred learning styles in the areas of training under discussion, which covers 14 universities in 8 countries (Table 3), has been collected from the literature to answer such a question.

Table 3

Characteristics of foreign universities compared to KNUTD

\begin{tabular}{|l|l|l|l|l|}
\hline $\begin{array}{l}\text { Field of } \\
\text { study }\end{array}$ & $\begin{array}{l}\text { Country (Faculty } \\
\text { numbers) }\end{array}$ & $\begin{array}{l}\text { Year of } \\
\text { study }\end{array}$ & $\begin{array}{l}\text { Number of } \\
\text { students }\end{array}$ & References \\
\hline Design & Denmark (1) & 1 & 77 & Kolmos, Holgaard, 2008 \\
\hline Technology & $\begin{array}{l}\text { USA (1), Canada (1), } \\
\text { Ireland (1), Brazil (1), } \\
\text { Australia (1) }\end{array}$ & $1,2,4$ & 1433 & $\begin{array}{l}\text { Livesay, Dee, Nauman, Hites, Livesay, } \\
\text { 2002; Seery, Gaughran, Waldmann, } \\
\text { 2003; Kuri, 2004; Rosati, 1996; 1999; } \\
\text { Fowler, McGill, Armarego, Allen, 2002 }\end{array}$ \\
\hline Pharmacy & $\begin{array}{l}\text { USA (1), United } \\
\text { Kingdom (1) }\end{array}$ & $1-2$ & 299 & $\begin{array}{l}\text { Laight, 2004; Teevan, Schlesselman, } \\
\text { 2011 }\end{array}$ \\
\hline Chemistry & $\begin{array}{l}\text { USA (1), Ukraine (2), } \\
\text { Denmark (1), Malaysia } \\
\text { (1), Brazil (1) }\end{array}$ & $1-4$ & 1200 & $\begin{array}{l}\text { Lopes, 2002; Klauk, 2007; Yaroshenko, } \\
\text { Derkach, 2012; Derkach, Starova, 2017 }\end{array}$ \\
\hline
\end{tabular}

As mentioned above, Figure 1 contains both experimental results and literature data. The profiles of KNUTD students major in chemistry almost entirely coincide with the profiles built on the average data of 1200 chemistry students from 5 countries of the world, including 2 Ukrainian universities (Yaroshenko, Derkach, 2012; Derkach, Starova, 2017). Evidently, such a coincidence gives evidence to the typicalness of the revealed learning profiles: future chemists in their majority demonstrate pronounced act, sen, vis and seq styles

Also, a good coincidence of learning preferences between KNUTD and other world universities is observed for students specialised in technology. They exhibit the most balanced profile of learning preferences: dominant styles have never exceeded $70 \%$, ranging from $51 \%$ to $69 \%$.

Comparison of the profiles of students of foreign universities and students of KNUTD in the fields of pharmacy and design reveals a very significant difference between them, although a more careful analysis allows one to explain the nature of such a discrepancy easily. 
Pharmacy students at KNUTD are much more active and also moderately more visual than pharmaceutical students from two universities in the US and UK. It is worthy to note that pharmaceutical students at KNUTD are studying in the field of industrial pharmacy, and, therefore, they are future technologists in the field of industrial pharmacy. Foreign students under comparison are studying at medical faculties of universities, and in the future, they will become medical pharmacists. Their training is aimed at work in medical institutions (pharmacies, etc.), and not in manufacturing companies. Thus, in spite of the similarity of the names, curricula, in particular, and educational environment, in general, are quite different for both specialities under comparison that results in the differentiation of student learning profiles.

It can be assumed that the learning profiles of pharmacy students of the above-mentioned foreign universities will be closer to the profiles of medical students. This assumption is consistent with the data of work (Hughes, Fallis, Peel, Murchison, 2009) where the learning preferences of future dentist students from the US and Canada were studied. The most significant discrepancy between KNUTD and foreign pharmaceutical students relates to act-ref and vis-vrb dimensions. For dental students (Hughes, Fallis, Peel, Murchison, 2009), the average preference of style act is equal to $22 \%$ compared to $71 \%$ and $49 \%$ for pharmacy students at KNUTD and foreign universities, respectively. For style vis, the analogous values are $37 \%, 77 \%$ and $68 \%$. Therefore, in both cases, the results of medical pharmacists are expectedly located between the results of future industrial pharmacists and medical students.

A very significant difference also exists between the profiles of design student of the KNUTD and the universities of the world. The domination of style vis over style vrb is typical for both samples, while the students of KNUTD are significantly more consistent, reflective and sensitive. The reason for such a discrepancy is similar to that described for pharmaceutical students. As for pharmacists, given the limited amount of data on universities in other countries, we were forced to compare profiles of similar but, nevertheless, somewhat different specialities. On the one hand, the KNUTD designers study at the Faculty of Fashion Industry and specialise in designing household items, such as clothing, footwear, interior decoration, and so on. On the other hand, international data are available for the students of one university specialised in design and architecture. Thus, these students are specialised primarily in engineering design and architecture in contrast to fashion design typical for KNUTD students.

Knowledge of an individual's learning style is of importance for improving personalised learning, instruction, or educational materials. However, the origin of the revealed differences in learning styles of students in different fields of studies is not entirely clear. Two polar explanations of this phenomenon, each of which has a confirmation in the scientific literature, are as follows.

In some studies, the emphasis is on the fact that the dominant learning styles are relatively stable and weakly variable characteristics of a person, which is formed under the influence of his/her psychological and physiological characteristics (Richardson, 2011; Salter, Evans, Forney, 2006; Gogus, Gunes, 2011).

The opposite view is that the dominant learning styles can change under the influence of external circumstances. Such influencing factors may include the field of study and type of material being studied, delivery mode, the age of an individual, his motivation and educational level, etc. (Bitran, Zuniga, Pedrals, Padilla, Mena, 2012; Mitchell, James, D'Amore, 2015; Gurpinar, Bati, Tetik, 2011). For example, in (Gurpinar, Bati, Tetik, 2011), the variability of learning styles of medical students has been researched during first two years of their study. Depending on the applied pedagogical approaches to teaching, 46 to $56 \%$ of students demonstrated the variability of learning profiles, while the rest of the students did not change them.

The current work compares the learning profiles for pharmaceutical students of KNUTD from the 1st to 5th (master) courses inclusively (Fig. 2).
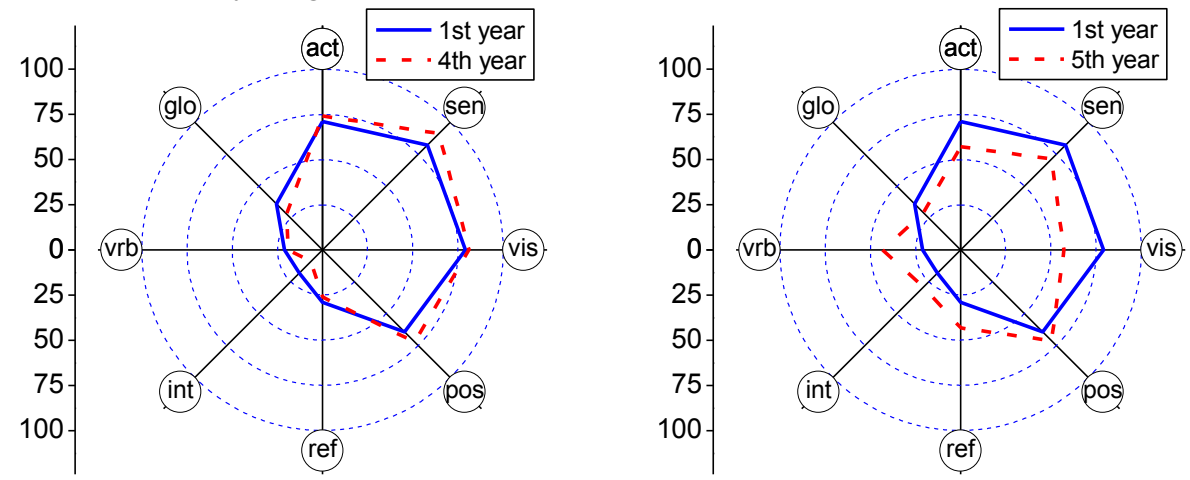

Fig. 2 Preferred learning styles of pharmacy students at KNUTD: $a-1$ st and 4th years of study, $b-1$ st and 5th years of study 
The difference in the preferred styles between students of the first and fourth year is minimal, while in going from the first to fifth course, the difference seriously increases in the direction of the growth of reflectivity, verbality and intuitiveness. In our opinion, the reason for such changes is not so much the natural change of personal styles but is mainly caused by the additional selection of students when they enter the graduate course at the 5 th year.

According to data from Fig. 2, a better balance in three of four directions of the learning styles is typical for graduate students. Compared to freshmen, they are more inclined to form abstract concepts (more intuitive), to reflections and observations (more reflective), and also more readily use the verbal channel of information transmission in addition to the visual pathway.

An additional argument in favour of the explanations presented above is the results of comparison of the learning styles of students and faculty members of two technology faculties at two Australian (87 students and 11 lecturers were surveyed in (Fowler, McGill, Armarego, Allen, 2002) and Canadian (858 students and 53 lecturers in (Rosati, 1996; 1999) universities (Fig. 3).

Apparently, among others, a stage of the additional personnel selection passed by former students before achieving professorship distinguishes faculty members and undergraduate students. Such a selection results in the fact that instructors on the average are more reflective and intuitive than their students. It is worthy to note that the direction of changing learning preferences from students to lecturers (Fig. 3) correlates well with changes in the transition from undergraduate to graduate students (Fig. 2).
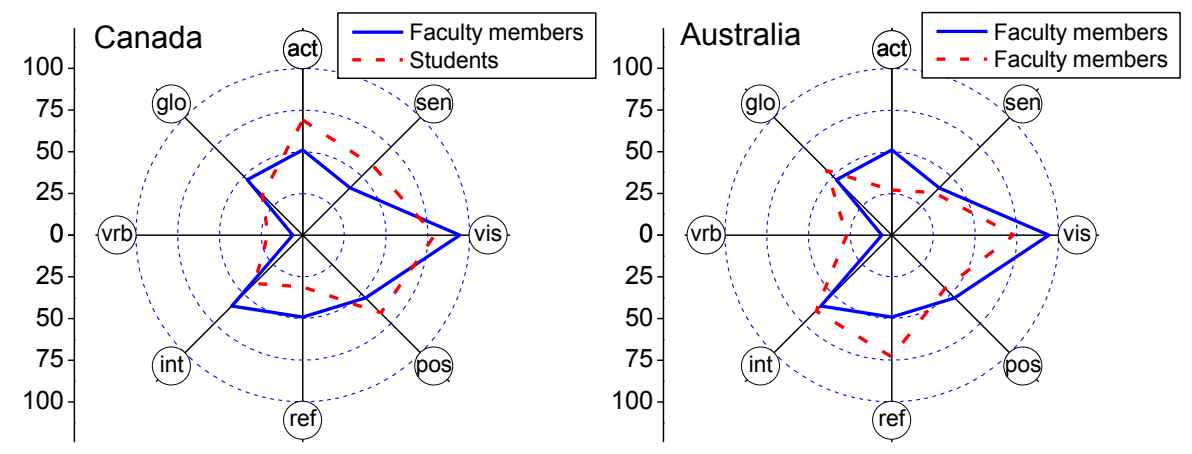

Fig. 3 Preferred learning styles of students and faculty members at Faculties of Technology of two Canadian (Rosati, 1996; 1999) and Australian (Fowler, McGill, Armarego, Allen, 2002) Universities

As is known from previous studies (Derkach, Starova, 2017; Derkach, 2013; 2011), the analysis of learning preferences is a prerequisite for the efficient use of ICTs in education. Therefore, the identified difference in learning preferences must be taken into account when developing educational materials. This statement can be illustrated by the example of teaching basic chemical disciplines to future chemists and pharmacists. As is known, the curricula for these specialities are very similar. However, as seen from Fig. 4, the educational preferences of students vary considerably. Thus, among pharmacists undeniably dominates the sensitive style of learning (more than 90\%), while among chemists, almost $20 \%$ prefer intuitive style.

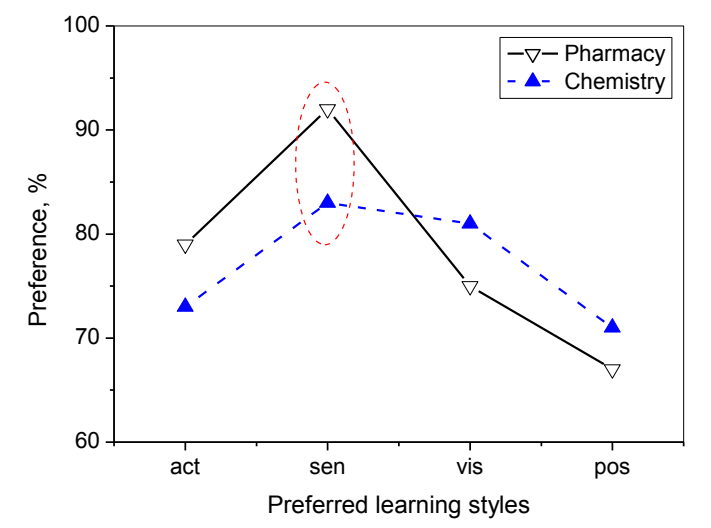

Fig. 4 Preferred learning styles of pharmaceutical and chemistry students (3rd year of study, KNUTD)

Students with sensitive style prefer the courses that are directly related to the real world, studying facts and experimenting. They pay attention readily to the details, work well practically, often solve problems by known methods; they are cautious and do not like surprises and difficulties. Students with intuitive style are innovators, hate tedious work and repetition. It is pleasant for them to work with abstract problems, 
formulation of concepts and mathematical dependencies. They do not enjoy courses that contain a lot of material for memorising and routine calculations, are bored studying details and more inventive.

According to the above-described information, the optimal pedagogical approach to the organisation of training, as well as the optimal teaching methods, should be different for students with different preferences (Table 4). Only those e-resources, which are acceptable for this or that learning style, are shown in the generalised form in Table 4. So, students with style sen are willing to take part in simulation labs and testing. Intuitive students, on the other hand, do not like testing, and among computer programmes, their preference is given to computer models that illustrate theoretical constructs and do not foresee manual manipulations.

Integration of methods and e-resources for sensitive/intuitive dimension

Table 4

\begin{tabular}{|l|l|l|}
\hline & Sensitive & Intuitive \\
\hline $\begin{array}{l}\text { A pedagogical } \\
\text { approach to } \\
\text { the } \\
\text { organisation } \\
\text { of learning }\end{array}$ & $\begin{array}{l}\text { To use teaching material with specific } \\
\text { examples of the implementation of theories and } \\
\text { their practical application. Solving tasks in a } \\
\text { particular order, implementation of procedures- } \\
\text { actions. Work in the laboratory }\end{array}$ & $\begin{array}{l}\text { To use teaching material with a guide to the } \\
\text { theory and conceptual examination. It is } \\
\text { necessary to provide arguments that connect } \\
\text { the facts being studied. Recommended } \\
\text { lectures, exercises, and innovative methods. }\end{array}$ \\
\hline $\begin{array}{l}\text { Learning } \\
\text { methods that } \\
\text { are best suited }\end{array}$ & $\begin{array}{l}\text { Verbal, visual, practical. } \\
\text { Simulation, problem-searching. } \\
\text { Experiment, execution of exercises; question } \\
\text { and answer method; a study based on solving } \\
\text { problems }\end{array}$ & $\begin{array}{l}\text { Modelling. } \\
\text { Role games, games and simulations. } \\
\text { The case method, project method. } \\
\text { Discussion panel. }\end{array}$ \\
\hline $\begin{array}{l}\text { The difference } \\
\text { in attitude to } \\
\text { e-resources }\end{array}$ & $\begin{array}{l}\text { It is useful to provide students with resources } \\
\text { that allow them to find the facts } \\
\text { independently, perform computer simulation } \\
\text { of laboratory works and undergo testing }\end{array}$ & $\begin{array}{l}\text { They prefer e-resources which provide } \\
\text { communication, computer simulation (3D } \\
\text { or quantum mechanics) and do not like to } \\
\text { be tested }\end{array}$ \\
\hline
\end{tabular}

\section{Conclusions}

The preferred learning styles of students of KNUTD of four different educational areas were determined on the base of the results of the survey conducted by the Felder-Soloman's method.

Chemistry and pharmacy students have similar learning profiles that are characterised by intense (70$80 \%$ ) advantages of styles act, sen, vis and seq over styles ref, int, vrb and glo, respectively. Learning profiles of future technologists and designers in most cases are better balanced than those of future chemists and pharmacists. The advantage of the above-mentioned styles act, sen, vis and seq is held true, but it usually is within the range of $55-70 \%$. The exception and feature of designers' profile is their very high preference for the visual style (more than $95 \%$ of respondents) over the verbal style.

The results obtained for pharmacists show the relative stability of learning profiles which have changed little over the years of undergraduate studies. At the same time, the comparison of freshmen with graduate students shows an increase in the number of masters with ref and vrb preferences. So, student profiles in these dimensions become more balanced in passing from undergraduate to graduate studies. The reasons are discussed with the consideration of data on the learning profiles of students and faculty members of foreign universities and seem to be associated with the availability of additional stages of selection in the career growth process, rather than with the rapid change of acquired learning styles. However, additional research is necessary to address the revealed discrepancies and issues in the field of learning preferences as well as to gain further information required for the implementation of effective teaching methods in a lecture hall.

Examples of optimal chemistry teaching of student groups with different preferences in a sensitivityintuitiveness direction are illustrated by differences in pedagogical approaches, acceptable learning methods and optimal e-resources that can provide effective learning.

\section{Acknowledgement}

The author would like to thank Ms Ya. Mikhalko for assistance in conducting the survey

\section{References:}

Bitran, M., Zúñiga, D., Pedrals, N., Padilla, O., Mena, B. (2012). Medical students' change in learning styles during the course of the undergraduate program: from 'thinking and watching' to 'thinking and doing'. Canadian Medical Education Journal, 3(2), e86-e97.

Cetin, B. (2015). Predicting academic success from academic motivation and learning approaches in classroom teaching students. Contemporary Issues in Education Research, 8(3), 171-180. https://doi.org/10.19030/cier.v8i3.9316

Chun Lok, K.L., Kuan, C.T. (2016). Personality, Learning Styles, Learning Motivation and Academic Performance: A Study of Macau Business Undergraduates in a Microeconomics Course. European Journal of Business \& Management, 8(21), 130-139. 
Coffield, F., Moseley, D., Hall, E., Ecclestone, K. (2004). Learning styles and pedagogy in post-16 learning A systematic and critical review. London, UK: The Learning and Skills Research Centre.

Derkach, T.M. (2011). Vplyv okremych styliv navchannia na zasvoennia studentamy khimichnykh znan [Influence of Special Aspects of Teaching Styles on Acquisition of Students Chemical Knowledge]. Pedagogika i Psykhologia Professiinoi Osvity, 5, 33-41.

Derkach, T.M. (2013). Application of ICT-based Learning Resources for University Inorganic Chemistry Course Training. European Researcher, 44(3-2), 649-653.

Derkach, T.M. (2016). Electronic resources in teaching basic chemical disciplines at universities. Science and Education, 12, 99-109. https://doi.org/10.24195/2414-4665-2016-12-19

Derkach, T., Starova, T. (2017). Preferred learning styles of students of natural field of study. Science and Education, 6, 51-56. https://doi.org/10.24195/2414-4665-2017-6-8

Felder, R.M., Spurlin, J. (2005). Applications, reliability and validity of the Index of Learning Styles. International Journal of Engineering Education, 21(1), 103-112.

Felder, R.M., Soloman, B.A. (1997). Index of Learning Styles. Retrieved from http://www4.ncsu.edu/felderpublic/ILSpage.html

Fowler, L., McGill, D., Armarego, J., Allen, M. (2002). Quantitative learning conversations: Constructivism and its application to learning in an engineering environment. In: Proc. 2002 Annual International Conference of the Higher Education Research and Development Society of Australasia (HERDSA). 7-10 July 2002, Perth, Western Australia, 254-262.

Gogus, A., Gunes, H. (2011). Learning styles and effective learning habits of university students: A case from Turkey. College Student Journal. 45(3) 586-600.

Gurpinar, E., Bati, H., Tetik, C. (2011). Learning styles of medical students change in relation to time. Advances in Physiology Education, 35(3), 307-11. https://doi.org/10.1152/advan.00047.2011.

Hughes, J. M. Fallis, D.W., Peel, J.L., Murchison, D.F. (2009). Learning Styles of Orthodontic Residents. Journal of Dental Education, 3, 319-327.

Ishak, N., Awang, M.M. (2017). The relationship of student learning styles and achievement in history subject. The International Journal of Social Sciences and Humanities Invention, 4(3), 3372-3377.

Klauk, E.E. (2007). Design and learning outcomes of Web-based instructional resources focused on the impacts of resource development on Native American lands. Thesis for the degree of Master of Science in Earth Sciences, Montana State University, USA.

Kolmos, A., Holgaard, J.E. (2008). Learning Styles of Science and Engineering Students in Problem and Project Based Education. Presented at 36th SEFI Annual Conference "Quality Assessment Employability and Innovation", 2-7 July 2008. Aalborg, Denmark. Retrieved from: http://vbn.aau.dk/en/publications/learning-styles-of-science-and-engineering-students-inproblem-and-project-based-education(db3daec0-8e55-11dd-93c5-000ea68e967b).html.

Kuri, N.P. (2004). Personality types and learning styles: propositions to engineering education. Thesis (Doctorate in Industrial Engineering), Federal University of São Carlos, Brasil.

Laight, D.W. (2004). Attitudes to concept maps as a teaching/learning activity in undergraduate health professional education: influence of preferred learning style. Medical Teacher, 26(3), 229-233. https://doi.org/10.1080/0142159042000192064

Livesay, G.A., Dee, K.C., Nauman, Jr. E.A., Hites, L.S., \& Livesay, G.A. (2002). Engineering Student Learning Styles: A Statistical Analysis Using Felder's Index of Learning Styles. In: Proc. 2002 ASEE Annual Conference and Exposition, Session 2430. Montreal, Quebec, Canada: American Society for Engineering Education.

Lopes, W.M.G. (2002). ILS - Inventário de Estilos de Aprendizagem de Felder-Soloman: Investigação de sua Validade em Estudantes Universitários de Belo Horizonte. Thesis for the degree of Master of Arts, Universidade Federal de Santa Caterina, Brasil.

Mitchell, E., James, S., D'Amore, A. (2015). How learning styles and preferences of first-year nursing and midwifery students change. Australian Journal of Education, 59(2), 158-168. https://doi.org/10.1177/0004944115587917.

Richardson, J.T.E. (2011). Approaches to studying, conceptions of learning and learning styles in higher education. Learning and Individual Differences, 21, 288-293. https://doi.org/10.1016/j.lindif.2010.11.015

Rosati, P.A. (1996). Comparisons of Learning Preferences in an Engineering Program. In: Proc.1996 Frontiers in Education Conference. 6-9 Nov 1996, Salt Lake City, UT, USA. 3, 1441-1444. https://doi.org/10.1109/fie.1996.568536

Rosati, P.A. (10-13 November, 1999). Specific Differences and Similarities in the Learning Preferences of Engineering Students. In: Proc. 29th ASEE/IEEE Frontiers in Education Conference, Session 12C1 (pp.17-22). San Juan, Puerto Rico. https://doi.org/10.1109/fie.1999.841625

Russo, C. J., Mertins, L., Ray, M. (2013). Psychological type and academic performance in the managerial accounting course. Journal of Education for Business, 88, 210-215. https://doi.org/10.1080/08832323.2012.672935

Salter, D.W., Evans, N.J., Forney, D.S.(2006). A Longitudinal Study of Learning Style Preferences on the Myers-Briggs Type Indicator and Learning Style Inventory. Journal of College Student Development, 47(2), 173-184. https://doi.org/10.1353/csd.2006.0022

Seery N., Gaughran, W.F., Waldmann, T. (2003). Multi-Modal Learning in Engineering Education. In: Proc. 2003 ASEE Conference and Exposition. Washington, D.C.: American Society for Engineering Education.

Surjono, H.D. (2015). The effects of multimedia and learning style on student achievement in online electronics course. Turkish Online Journal of Educational Technology, 14(1), 116-122.

Teevan, C.J., Li, M., Schlesselman, L.S. (2011). Index of Learning Styles in a U.S. School of Pharmacy. Pharmacy Practice, 9(2), 82-87. https://doi.org/10.4321/s1886-36552011000200004

Velusamy, B., Anouncia, S.M. (2013). A narrative review of research on learning styles and cognitive strategies. Journal of Theoretical and Applied Information Technology, 52(1), 23-29.

Wilson, K., Narayan, A. (2014). Relationships among individual task self-efficacy, self-regulated learning strategy use and academic performance in a computer-supported collaborative learning environment. Educational Psychology, 36(2), $236-253$. https://doi.org/10.1080/01443410.2014.926312

Yaroshenko, O.G., Derkach, T.M. (2012). Porivnyalnyi analiz styliv navchannia studentiv riznych spetsialnostei [Comparative analysis of learning styles for students of different specialities]. Pedagogika i Psykhologia, 1, 43-47. 